\title{
The Relationship Between Teachers' Efficacy and Classroom Management
}

\author{
Aye Aye Myint Lay \\ Department of Education and Psychology, Eotvos Lorand University \\ 1076, Thokoly street, Budapest, Hungary \\ E-mail: ayeayemyintlaysuoe@gmail.com
}

\begin{abstract}
Teacher efficacy takes a key role in improving quality education in every nation. Efficacious teachers are more likely to stay in their teaching professions, spend more time teaching, make greater efforts in classroom management. Myanmar (known as Burma) is situated in mainland Southeast Asia and the population is about 54 million. Education standard in Myanmar is falling since there is an inadequacy of teacher training programs and other professional development programs for teachers. Lack of research focusing on measuring teacher efficacy and its impact on teaching learning situation in Myanmar context provided inspiration to conduct this study, which focused on investigating the relationship between teachers' efficacy and classroom management practice. The purpose of this research is to study the relationship between teachers' efficacy and classroom management practice of primary teachers in Monywa Township in Myanmar. Monywa is a capital city and the largest city in Sagaing Region, located in the north-western part of the country. It has a good reputation in its education practices. A survey research design is used in this study. Participants included 151 primary school teachers from basic education primary schools. The Teachers' Sense of Efficacy Scale (TSES) designed by Tschannen-Moran, et al., (2001) was also employed to examine their efficacy beliefs and Little-Akin (2007)'s items for classroom management was revised and validated to measure classroom management practices. Results of the survey indicate that if teachers' efficacy is high, their classroom management practices will be high. Highly efficacious teachers are more likely to learn and use new approaches and strategies for teaching, use effective management techniques.
\end{abstract}

Keywords: Teacher efficacy, Classroom management, Engagement, Instructional strategies

DOI: $10.7176 / \mathrm{JEP} / 12-26-03$

Publication date:September $30^{\text {th }} 2021$

\section{Introduction}

There is no doubt that education is the most important thing for the sustainable development of any nation. The aim of education is to produce qualified and well-developed citizens. The quality of learners is determined by the quality of teachers. In other words, the quality of teachers largely determines the quality of education in a society. Therefore, teachers play a crucial role in building a modern developed nation. Through quality teachers, the new generation can be equipped with $21^{\text {st }}$ century skills in order to propel a country to development and progress.

A person's belief in his or her ability to produce desired results by his or her own actions is critical in determining one's capability to complete tasks. It is what Bandura (1997) identified as self-efficacy. He describes that self-efficacy has two components: efficacy expectancy and outcome expectancy. Self-efficacy expectancy allows a teacher to determine if he or she is capable of engaging in a given activity based on his/her abilities. Outcome expectancy enables a teacher to decide if he or she has completed a task to the level desired (Tschannen-Moran \& Woolfolk Hoy, 1998). Many scholars point out that self-efficacy can positively influence the level of aspiration of teachers, their innovation and persistence.

Obviously, effective teachers have belief not only in themselves but also in their instruction, and management skills. Ng, Nicholas, and Alan (2010) claimed that "teachers' beliefs are the ideas that influence how they conceptualize teaching" (p. 278). This self-conception is central to teacher efficacy. Research has clearly found that teacher efficacy has an impact on teacher "performance, commitment, and professional retention" (Ware \& Kitsantas, 2007). Accordingly, teachers with teacher efficacy can organize learning activities, regulate student behaviors (particularly negative behaviors that hinder learning), evaluate progress and offer hands-on work to enhance students' learning. Thus, teacher efficacy is one of the important qualities of teachers which will improve student learning outcomes, and eventually quality education.

Significantly, experts and parents alone cannot bring students' academic achievement without critical effort of teachers. Teacher's good classroom management skill is essential in this aspect. Classroom management style has changed in the 21 st century with knowledge transmission and production. Classroom management approaches such as corporal punishment and yelling are intolerable in the current society. That is why teachers should focus to be professional and well-manageable. Classroom management fosters more class participation, self-discipline, ultimately, effective learning. Classrooms well-managed by teachers can provide safety and freedom for students. By attending to the teacher's instruction without being disturbed, students can store the 
instruction in their long-term memory and use it for the future.

A number of researchers claim that teachers' sense of efficacy is associated with classroom management and organization strategies. Teachers with high efficacy are able to motivate students to learn and are capable of engaging students in learning even if students are disruptive (Dipabile, 2012). Teacher efficacy can deeply influence on classroom management. It is said that teachers with high efficacy can be effective managers and student counselors. They know how to handle misbehaving students; they can effectively organize classrooms in which learning and good performance will be achieved (Dipabile, 2012). For these reasons, the relationship between teachers' efficacy and classroom management, one important aspect that teachers encounter in their career, ought to be investigated.

\section{Review of Related Literature}

Many scholars discuss teacher efficacy from various perspectives. According to Tschannen- Moran and Hoy (2007), efficacy is a kind of ability that can bring the desired results. Teacher efficacy has been described by Armor et al., as "teachers' beliefs in their abilities to affect student performance" (Armor, Oseguera-Conroy, Cox, McDonnell, Pascal, Pauly, and Zellman, Berman and McLaughin, Gibson and Dembo, cited in Dellinger, Bobbett, Olivier, \& Ellett, 2008, p. 753). Futhermore, "teacher efficacy is sometimes considered to be a general indicator or predictor of teaching effectiveness" (Melby, 2001, p. 5). Obviously, teacher self-efficacy can impact on the growth of beliefs about being a good teacher. Therefore, teacher self-efficacy can influence teachers to be effective and manage difficult students.

In 1954, Rotter developed attribution theory and explain the concept "locus of control", concentrating on how individuals define the causes of their successes and failures. The theory attempts to explain people's excuses, especially regarding success or failure. Therefore, this theory is vital to education (Slavin, 2006). Internal locus of control is also called self-efficacy, the idea that an individual's behavior can cause the difference between success and failure (Bandura, Pajares, \& Schunk; Pajares \& Zimmerman as cited in Slavin, 2006). Rotter's (1966) theory of internal locus of control became a foundation of teacher efficacy research. Based on this, other researchers contended that the teacher's reinforcement can enhance motivation and performance and consequently, contributes to a higher teachers' self-efficacy.

However, Bandura's (1977) defines self-efficacy as "the outcomes of cognitive process in which people construct beliefs about their capacity to perform at a given level of competence" (p. 480). He suggested that people's beliefs have an effect on their efforts particularly their determination or flexibility when encountering problems, and the ways they cope with anxiety they experience in dealing with challenging situations (Bandura, 1977). According to Cheung (2008), Bandura explained that personal teaching efficacy and professional teaching efficacy are distinct components in teacher efficacy. The first one refers to an individual's accountability, how a teacher acknowledges student learning while the second is the teacher's conviction that every teacher possesses the capabilities to affect what Wheatley termed "external factors" (as cited in Cheung, 2008).

With comparative perspective, educators claimed that Rotter's internal locus of control and Bandura's perceived self-efficacy and locus of control are roughly the same" (Goddard et al., 2000). Bandura (1977) mentioned mental abilities which can formulate people's beliefs. On the other hand, Rotter (1966) investigated teachers' internal and external beliefs. Dellinger et al. (2008) viewed that the model of self-efficacy theory (Bandura, 1977) is characterized by connections of the self to the community and involves "behavior, internal personal factors (cognitive, affective, and biological events") and the external environment as reciprocating factors.

Self-efficacy model of Bandura (1997) is vital in that it helps us to understand how an individual's behavior can be influenced by the environment, as well as by biological factors. The biological part of the model means that learners also acquire certain skills from their parents and other siblings. In this regard, some students could be intelligent or low performer because of their genetic make-up and teachers ought to aim to understand factors that exist both within and beyond the learner. Later, many scholars prove that gene takes a key role, in some extent, in student achievement and the environment and biological factors can affect both teachers and students positively or negatively. Dellinger et al. (2008) state that personal factors and the environment can impact on behavior, and sometimes, personal factors may be influenced by the behavior and environment.

\subsection{Teacher Efficacy}

Bandura (1997) proposed the four major influences on efficacy: mastery experience, physiological arousal, vicarious experience, and verbal persuasion. Mastery experiences are a kind of source of efficacy information. The perception that a performance has been successful raises efficacy, which contributes to the expectation that performance will be proficient in the future. The level of emotional and physiological arousal during teaching adds to self-perceptions of teaching competence (Bandura, 1996). Moderate levels of arousal can improve performance by focusing attention and energy on the task (Tschannen-Moran et al., 1998, p. 217).

Vicarious experiences are those in which the skill in question is modeled by someone else. The degree to 
which the observer identifies with the model moderates the effect on the observer's self-efficacy (Bandura, 1977). Social persuasion may entail a pep talk or specific performance feedback from a supervisor or a colleague, or it may involve the general chatter in the teachers' lounge or in the media about the ability of teachers to influence students (Bandura, 1986, Johnson, 2010).

Based on Bandura's work, Tschannen-Moran et al., (1998) have set the sources of teachers' self- efficacy (mastery experience, verbal persuasion, vicarious experience, and physiological arousal) how teacher efficacy operates.

The proficiency of a performance creates a new mastery experience, which provides new information that will be processed to shape future efficacy beliefs. Greater efficacy leads to greater effort and persistence, which leads to better performance, which in turn leads to greater efficacy (Tschannen-Moran, et al., 1998).

According to Tschannen- Moran, Hoy \& Hoy (1998), teachers' efficacy is the teachers' belief in his or her capability to organize and execute courses of action required to successfully accomplish a specific teaching task in a particular context. It also includes the teachers' motivation to persist when face with setbacks and their willingness to exert effort to overcome difficulties.

A self-assessment of personal teaching capabilities and limitations needs to be specific to the task (analysis) of teaching. Teacher evaluations of their work can have an impact on their attempts to achieve their goals in teaching, and need for patience when they encounter difficulties. Woolfolk Hoy, et al. (2006) proposed that "these decisions and behaviors lead to outcomes that then become the basis of future efficacy judgments" ( $p$. 727).

\subsection{Classroom Management}

"It is probably no exaggeration to say that classroom management has been a primary concern of teachers ever since there have been teachers in the classroom" (Marzono, 2003). Classroom management is certainly concerned with behavior, but it can also be defined more broadly as involving the planning, organization and control of learners, the learning process and the classroom environment to create and maintain an effective learning experience." (Doyle, 1986). Management will help the day run more smoothly, along with lessons. Teachers need management plans including guidelines for success, classroom rules, an attention signal, expectations for activities and transitions, encouragement procedures, beginning and end of day routines, procedures for managing student work, procedures for managing independent work periods, and corrections procedures for misbehavior.

Grossman (1995), as cited in the book, Classroom Behavior Management, developed the logical consequences model and claimed that students behave more appropriately when they suffer logical consequences and the unwanted behavior will be controlled. He also believed that the motivation for classroom behavior was to attract attention because many students are motivated by gaining the attention from teachers or peers. Another aspect of Grossman's (1995) model is that students can learn to understand their own motives and eliminate misbehavior by having teachers help them explore why they behave as they do. Similarly, Marchand-Martella (2012) explained an assertive discipline model explained in Comprehensive Behavior Management. It is mentioned in the assertive discipline model that when the students do not behave in a manner consistent with teacher expectations, teachers can respond in one of three ways: non-assertively by surrendering to their students, hostilely by showing anger, or assertively by calmly insisting and assuming that students will fulfill these expectations.

Several research studies reveal that the vital factor in succeeding in management is the teacher's capabilities to supervise and organize instruction (Brophy, 1988). Organized instruction will lead to students' engagement in the learning process. On the other hand, Evertson (1985) claimed that teaching competence, generating and retaining order in the classroom setting play a crucial role in effective teaching. Furthermore, Marcia Tate (2007) found that the key to classroom management is planning. He said that an ineffective teacher appears to be annoyed, frustrated, and often engage with students in power struggles in which they are destined to lose. Proactive management comes from teachers who are capable of putting proactive plans in place so that the majority of potential behavior problems don't ever occur. Proactive teachers can divide the content into meaningful chunks and teach each chunk by allowing students to practice what they have just learned through active engagement strategies. He states the proactive characteristics to effective classroom managers such as leading the class by modeling the expected behaviors, building resiliency in students by gathering and interpreting student date, developing a positive relationship with each student, taking care of behavior problems quietly and quickly, realizing that student behavior can be affected by positive physical and emotional environment, and assisting students in perceiving the value or importance of the task at hand.

Unfortunately, there is little research in the field of teacher self-efficacy for classroom management. However, among the research that exists, some researchers imply that criticizing students for failing and showing-impatience when confronted with challenges in problematic circumstances were found to be related to a low personal teacher efficacy (Gibson \& Dembo, 1984). On the other hand, Morris-Rothschild and Brassard 
(2006) suggests that when teachers possess a strong sense of personal teaching efficacy, they are more likely to have impressive classroom results because they establish good relationships with students and help them learn. Recent research showed that teachers' classroom management self-efficacy positively related to aspects of their perceived classroom management, particularly during early career (Lazarides, et al., 2020). Moreover, Gencer and Cakiroglu's (2007) findings revealed that teachers' differing beliefs about classroom management are critical in effective instruction.

\section{Research Questions}

1. What is the current teachers' efficacy level of primary teachers in Monywa Township?

2. What are the current classroom management practices of primary teachers in Monywa Township?

3. Is there any relationship between teachers' efficacy and classroom management practices of primary teachers in Monywa Township?

\section{Methodology}

This study used a quantitative research design. As quantitative research method, data were collected with questionnaires using Likert Scale. The Teachers' Sense of Efficacy Scale (TSES) long form (24 items) designed by Tschannen-Moran, et al., (2001) was also employed to examine their efficacy beliefs. The Teacher Sense of Efficacy Scale (TSES) involves three subscales: efficacy in student engagement, instructional strategies and classroom management. Little-Akin (2007)'s items for classroom management involving two dimensions: instructional management and behavior management (12 items for each dimension) was used to study their classroom management skills.

The subjects of this study involved 151 teachers from selected basic education primary schools. Collected data was analyzed by the use of central tendency measures, and Pearson-product moment correlation coefficient through SPSS software version 26.

\subsection{Population and Sample}

This study will be limited to selected basic education primary schools in Monywa Township. In Monywa Township, there are 89 basic education primary schools- 38 schools in urban area and 51 schools in rural area. Among them, 8 basic education primary schools- 4 schools in schools in urban area and 4 schools in rural area, are selected using systematic random sampling method.

First, basic education primary schools are labeled as School A, School B, School C and School D, School E, School F, School G and School H. Table 4.1 shows the number of teachers (primary teachers) participated in this study.

\subsection{Data Analysis}

Descriptive statistics were calculated for teacher efficacy and their classroom management practices using Statistical Package for the Social Sciences Software (SPSS) version 26. The data was organized by subscales, calculated. The data sample from the TSES and classroom management practices were placed in the SPSS data analysis program. Finally, Pearson-product moment correlation coefficient was utilized to know the relationship between teachers' efficacy (dependent variables) and their classroom management practices (independent variables).

\section{Findings}

\subsection{Level of Teacher Efficacy}

According to the table 5.1, the teachers' efficacy was high in all dimensions (student engagement, instructional strategies, classroom management) of teachers' efficacy because the mean values $(3.69,3.85,3.92)$ were between the ranges of (3.50-4.49).

\subsection{Level of Classroom Management}

According to the table 5.2, the teachers had high level of behavior management because the mean value was between the ranges of (3.50-4.49) but they had moderately high level of instructional management because the mean value was between the ranges of (2.50-3.49).

\subsection{Relationship between Teacher Efficacy and Classroom Management}

Table 5.3 shows the correlation between teachers' efficacy and classroom management. It was found that there was a significant correlation $\gamma=.636, \mathrm{p} \leq 0.001$. This means that if teachers' efficacy is high, their classroom management will be high or if teachers' efficacy is low, their classroom management will be low. The results also show that there was a significant moderate relationship between teachers' efficacy and classroom management. 


\section{Discussion}

In the study, teachers' efficacy is divided into three dimensions: (student engagement, instructional strategies, classroom management). The dimension of student engagement involved getting through to the most difficult student, helping students think critically, motivating students who show low interest in school work, getting students to believe they can do well in school work, helping students value learning, fostering student creativity, improving the understanding of a student who is failing, assisting families in helping their children do well in school. The efficacy of teachers was high in this dimension.

The area of instructional strategies involved responding to difficult questions from students, gauging student comprehension of what you have taught, crafting good questions for students, adjust lessons to the proper level for individual students, using a variety of assessment strategies, providing an alternative explanation for example when students are confused, implementing alternative strategies in classroom, providing appropriate challenges for very capable students. The efficacy of teachers was high in instructional strategies.

Classroom management included the functions of controlling disruptive behavior in the classroom, making expectations clear about student behavior, establishing routines to keep activities running smoothly, getting children to follow classroom rules, doing to calm a student who is disruptive or noisy, establishing a classroom management system with each group of students, keeping a few problem students form ruining an entire lesson, responding to defiant students. The efficacy of teachers was high in these functions of classroom management.

These results for Teachers' Efficacy are important because they show the teacher's impact on student achievement. Research shows that teachers' sense of efficacy has an effect on students' achievement. Ross suggested that highly efficacious teachers are more likely to (1) learn and use new approaches and strategies for teaching, (2) use management techniques that enhance student autonomy and diminish student control, (3) provide special assistance to low achieving students, (4) build students' self-perceptions of their academic skills, (5) set attainable goals, and (6) persist in the face of student failure (Woolfolk-Hoy \& Spero, 2005, p.345).

In studying the relationship between teachers' efficacy and classroom management, there was moderately positive relationship between teachers' efficacy and classroom management. Considering the positive and significant correlation between teacher self-efficacy and classroom management, the researcher suggests that teacher training programs should concentrate on activities and practices that could improve management skills. As a result, they can have high self-efficacy beliefs. According to Guskey \& Passaro (1994), these beliefs can influence their students' learning despite facing several obstacles such as a lack of motivation or problem behavior (Fackler \& Malmberg, 2016).

RimmKaufman \& Sawyer (2004) reported that more efficacious teachers are more likely to introduce new teaching approaches and stricter classroom management. They are more likely to create a positive atmosphere (Ashton et al., 1983). Malmberg et al. (2014) reported that a positive influence of TSE on students' achievement. Students in classes of more self-efficacious teachers were more engaged in their learning (Guo et al., 2011; Pas et al., 2012) and, vice versa, teachers with higher TSE were found to better engage students in the lessons (Holzberger et al., 2014, Fackler \& Malmberg, 2016)

According to Fackler \& Malmberg (2016), teachers in private schools feel more efficacious than teachers in public school. It is consistent with previous studies (Woolfolk et al., 1990). Private schools are often carefully chosen by parents who are highly educated, who are more affluent, and who also want to achieve a good education for their children as well. Thus, this might be an effect over and above the parental educational level (Fackler \& Malmberg, 2016).

Overloaded classes can hinder learning by interfering with curriculum goals. Another obstacle is that even if teachers have high efficacy and intend to employ various teaching methods, they cannot be succeed. Overcrowded classrooms are not a new problem. In Report of the National Commission on Education (1993), it was suggested that "The teacher is able to give individual attention to the child; to give more work and mark it; to get to know the strengths and weakness of children better and therefore devise appropriate remedial measures and more effectively monitor progress of children in class". As long as classrooms are overcrowded, providing students with a quality education will not be achieved.

\section{Conclusion}

The findings give interesting evidence that if teachers' efficacy is high, their classroom management practices will be high. There was moderately positive relationship between teachers' efficacy and classroom management practices. This result might mean that efficacious teachers can develop student learning and accomplishments through interactive instruction with the help of effective classroom management practices. They are more capable and knowledgeable in dealing with classroom discipline. The result is consistent with Jeon's (2017) argument that teachers with a higher level of efficacy have the ability to enrich and enhance student achievement and expected outcomes of teaching and learning environment through mechanisms such as sustained interaction with students, a warm classroom climate, innovative classroom management, and generally supportive attitudes (Jeon, 2017). 
By understanding the important role of teacher efficacy and classroom management to quality education, policy makers and administrators are able to provide effective professional in-service trainings that can help enhance teaching efficacy. This study throws insights to curriculum planners and developers of teacher education institutions for adding more strategies that promote the development of teacher efficacy beliefs in terms of student engagement, instructional strategies and classroom management.

\section{Recommendation for Further Research}

This was a quantitative study by nature with the aim of investigating teacher efficacy among primary teachers in Monywa Township. A mixed method should be conducted to gain more insight on teachers' sense of efficacy. Furthermore, more research on teachers' efficacy is still needed in secondary schools and teacher training colleges to raise pre-service teachers' awareness about teacher efficacy. Future research could focus on the factors that affect teacher self-efficacy and classroom management is necessary to determine what makes a good classroom manager. Further studies need to expand teacher efficacy and teachers' concomitant beliefs, strategies for dealing with internalizing problem behavior.

\section{References}

Andedoyin, O. (2010). Teacher Self-Efficacy Enhancement and School Location. [Online] Available: http://files.eric.ed.gov>fulltext (October 7, 2017)

Ashman, F., \& Conway, R. (1997). An Introduction to cognitive education. London: Routledge.

Bandura, A. (1977). Self-efficacy: Toward a unifying theory of behavioral change. Psychology Review, 84(2), 479-507. [Online] Available: http://www.uky.edu/ eushe2/Bandura/Bandura1977PR.pdf (June 6, 2017)

Bandura, A. (1986). Social Foundations of thought and action: A social cognitive theory. New Jersey: Englewood Cliffs, Prentice Hall.

Bandura, A. (1995). Self-efficacy in changing societies. Cambridge University Press. New York.

Bandura, A. (1997). Self-efficacy: The exercise of control. New York. Freeman \& Co.

Cerit, Y. (2010). Teacher Efficacy Scale: The Study of Validity and Reliability and Pre-service Classroom Teachers' Self-Efficacy Belief. [Online] Available:http://eku.comu.edu.tr>article>download (June 16, 2017)

Cheung, H. Y. (2008). Teacher Efficacy: A comparative study of Hong Kong and Shanghai primary in-service teachers. The Australian Educational Researcher, 35, (1) 103-123.

Dellinger, A. M., Bobbet, J. J., Oliver, D. F., \& Ellet, C. D. (2008). Measuring teachers' self-efficacy beliefs: Development and use of the TEBS-Self. Teaching and Teacher Education, 24,751-766.

Dipabile, W. T. S. (2012). A Review of Literature On Teacher Efficacy And Classroom Management. Educational Psychology \& Counseling Publications and Other Works. 9(2), 79-92. [Online] Available: http://trace.tennessee.edu/cgi/viewcontent.cgi?article=1031\&context=utk_educpubs (May 7, 2017)

Dipabile, W. T. S. (2012). Teacher Efficacy and Classroom Management among Botswana Junior Secondary School Teachers. [Online] Available:

https://trace.tennessee.edu/cgi/viewcontent.cgi?referer=https://www.google.com/\&httpsredir=1\&article=2567\&c ontext=utk_graddiss (October 17, 2017)

Evertson, C. M. (1985). Training teachers in classroom management: an experimental study in secondary school classrooms. Journal of Educational Research, 79(1), 51-58.

Evertson, C. M. \& Weinstein, C. S. (Eds) (2006). Handbook of Classroom Management, Research practice and contemporary issues, Mahwah, NJ: Larence Erlbaum Associates, Inc.

Fackler, S. \& Malmberg, L., E. (2016). "Teachers' self-efficacy in 14 OECD countries: Teacher, student group, school and leadership effects." Teaching and Teacher Education. 56: 185-195.

Fives, H., \& Buehl, M. M. (2009). Examining the Factor Structure of the Teachers' Sense of Efficacy Scale. Journal of Experimental Education, 78 (1), 118-134

Goddard, R., Hoy, K., and Hoy, W. A. (2000). Collective Teacher efficacy: Its meaning, measure and impact on student achievement. American Educational Research Journal, 37 (2), 479-507.

Kalra, V. (2008). School Efficiency. New Delhi: A P H Publishing Corporation.

Johnson, D. (2010). Learning to Teach: The Influence of a University-School Partnership Project on Pre-Service Elementary Efficacy for Literacy Instruction Teachers'. Reading Horizons: A Journal of Literacy and Language Arts, 50 (1). [Online] Available: https://scholarworks.wmich.edu/reading horizons/vol50/iss1/4 (May 20, 2017)

Karadag, E., Cogaltay, N. \& Su, A. (2018). School principal self-efficacy: a study on self-efficacy levels of the Turkish primary school principals. Journal for Educators, Teachers and Trainers, Vol. 9(1). $208-221$.

Khin Mar Ni, Dr. (2008). A study of teachers' efficacy for promoting students' logical Thinking skills in Yangon Division (Doctoral Dissertation). Yangon University of Education.

LaMorte, W. W. (2016). The social cognitive theory. Boston University School of public Health.

Lazarides, R. Watt, H.M.G. \& Paul W. Richardson, P. W. (2020). Teachers' classroom management self- 
efficacy, perceived classroom management and teaching contexts from beginning until mid-career. Volume 69. [Online] Available: https://www.sciencedirect.com/science/article/pii/S0959475219302245

Lewis, R., Romi, S., Qui, X., \& Katz, Y. J. (2005). Teachers' classroom discipline and student misbehavior in Australia, China and Israel. Teaching and Teacher Education, 21,729-741.

Linsin, M. (2013). The Classroom Management Secret. San Diego, California.

Little-Akin, K. 1., Little, S. G., \& Laniti, M. (2007). Teachers' use of classroom management procedures in the United States and Greece: a cross-comparison cultural. School Psychology International, 28, 1, 52-62.

Mishra, R. C. (2010). Classroom Management. New Delhi: A P H Publishing Corporation.

Sanford, J. P., \&, Evertson, C. A. (1985). Classroom management in low SES junior high: Three case studies. Journal of Teacher Education, 32 (1), 34-38.

Shaughnessy, M. (2004). An interview with Anita Woolfolk: the educational psychology of teacher efficacy. Educational Psychology Review, 16 (2), 153-176.

Slavin, R. E. (2006). Educational Psychology: theory and practice, eighth edition. London: Pearson.

Tschannen-Moran, M. T., Hoy, W. A., \& Hoy, W. K. (1998). Teacher Efficacy: Its meaning and measure. Review of Educational Research, 68 (2), 202-248.

Waitshega Tefo Smitta Dibapile (2012). A review of literature on teacher efficacy and classroom management. University of Tennessee - Knoxville, Educational Psychology \& Counselling.

Ware, H; \& Kitsantas, A. (2007). Teacher and collective Efficacy beliefs as predictors of professional commitment. The Journal of Educational Research, 100(5), 303-309.

Woolfolk, A. E., Rosoff, B., \& Hoy, W. K. (1990). Teachers' sense of efficacy and their beliefs about managing students. Teaching and Teacher Education, 6 (2), 137-148.

Woolfolk-Hoy, A., Spero, R. B. (2005). Changes in teacher efficacy during the early years of teaching: A comparison of four measures. Teaching and Teacher Education. 21 (2005) 343-356

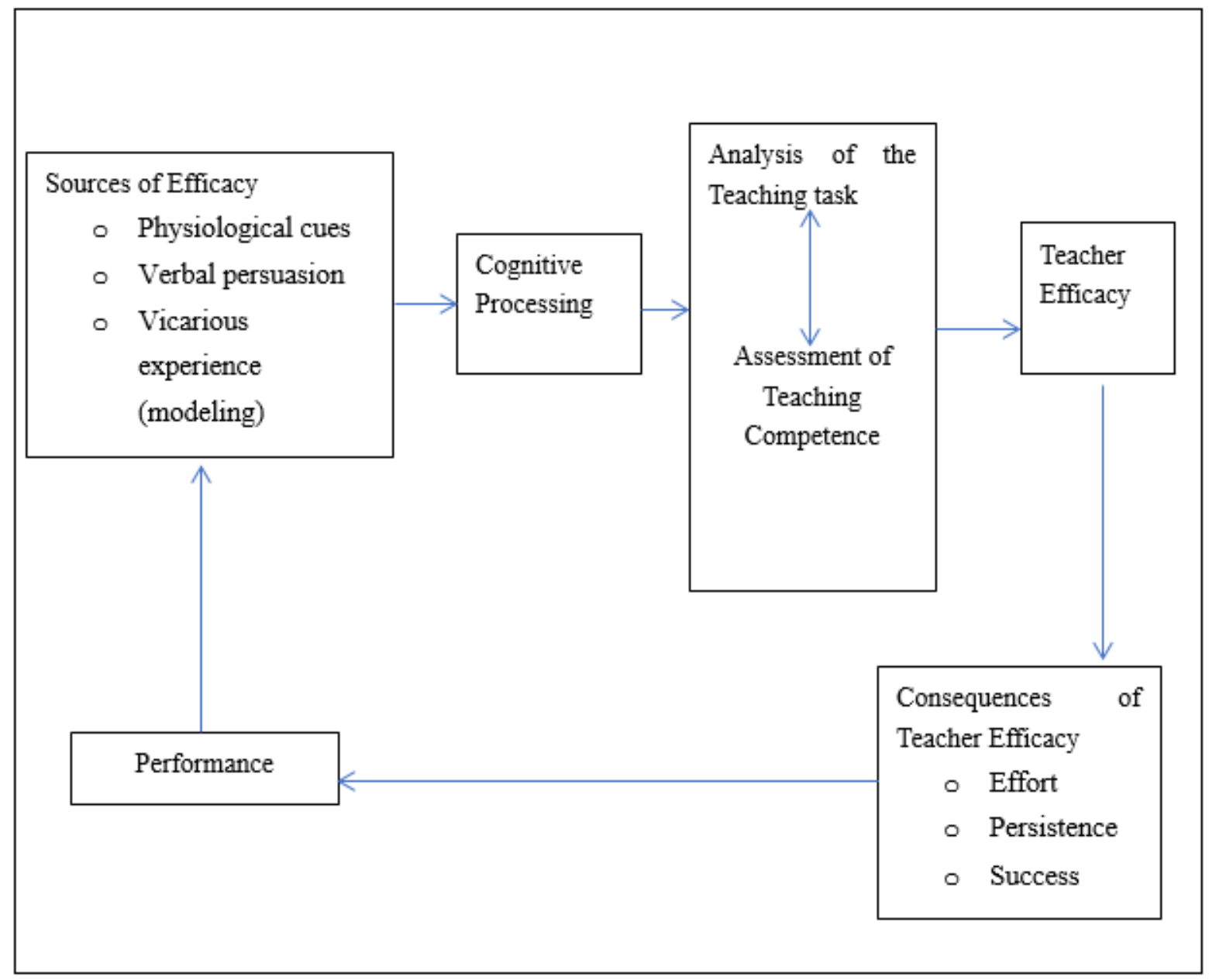

Figure 1. A Model of Perceived Efficacy

SOURCE Adapted from Tschannen-Moran Woolfolk Hoy and Hoy (1998) 
Table 4.1 Number of Teachers Participated in the Main Study

\begin{tabular}{|c|c|}
\hline School & Number of Teachers \\
\hline A & 20 \\
\hline B & 21 \\
\hline C & 13 \\
\hline D & 16 \\
\hline E & 21 \\
\hline F & 18 \\
\hline G & 18 \\
\hline H & 24 \\
\hline Total & 151 \\
\hline
\end{tabular}

Table 5.1 Level of Teacher Efficacy

\begin{tabular}{|l|l|l|l|}
\hline Variables & $\mathrm{N}$ & Mean & Std. Deviation \\
\hline Student Engagement & 151 & 3.69 & .553 \\
\hline Instructional Strategies & 151 & 3.85 & .503 \\
\hline Classroom Management & 151 & 3.92 & .512 \\
\hline Overall Efficacy & 151 & 3.80 & .402 \\
\hline
\end{tabular}

1.00-1.49=Very Low, 1.50-2.49= Moderately Low, 2.50-3.49= Moderately High,

3.50-4.49=High, 4.50-5.00= Very High

Table 5.2 Level of Classroom Management

\begin{tabular}{|c|c|c|c|}
\hline Variables & $\mathrm{N}$ & Mean & SD \\
\hline Behavior Management & 151 & 3.96 & 0.56 \\
\hline Instructional Management & 151 & 3.31 & 0.58 \\
\hline Overall Classroom Management & 151 & 3.35 & 0.53 \\
\hline
\end{tabular}

1.00-1.49=Very Low, 1.50-2.49= Moderately Low, 2.50-3.49= Moderately High,

3.50-4.49=High, 4.50-5.00= Very High

Table 5.3 Correlation between Teachers' Efficacy and Classroom Mangement Correlations

\begin{tabular}{|ll|c|c|}
\hline & & Efficacy & $\begin{array}{c}\text { Classroom } \\
\text { Management }\end{array}$ \\
\hline Efficacy & Pearson Correlation & 1 & $.636^{* *}$ \\
& Sig. (2-tailed) & & .000 \\
& $\mathrm{~N}$ & 151 & 151 \\
\hline Classroom & Pearson Correlation & $.636^{* *}$ & 1 \\
Management & Sig. (2-tailed) & .000 & 151 \\
& $\mathrm{~N}$ & 151 & \\
\hline
\end{tabular}

**. Correlation is significant at the 0.01 level (2-tailed). 